\title{
Phenological and physicochemical properties of Pereskia aculeata during cultivation in south Brazil
}

\author{
Débora O Silva $^{1}$; Maurício Seifert ${ }^{1}$; Gustavo Schiedeck ${ }^{2}$; Juliana S Dode ${ }^{1}$; Leonardo Nora ${ }^{1}$ \\ ${ }^{1}$ Universidade Federal de Pelotas (UFPel), Capão do Leão-RS, Brazil; deca116@hotmail.com; mau.seifert@gmail.com; ju_dode@hotmail. \\ com; 1.nora@me.com; ${ }^{2}$ Embrapa Clima Temperado, Pelotas-RS, Brazil; gustavo.schiedeck@cpact.embrapa.br
}

\begin{abstract}
Pereskia aculeata, known as ora-pro-nobis in Brazil, is native from tropical dry forests. This Cactaceae plant possesses succulent and edible leaves, which contain high amounts of protein, minerals, vitamins and fiber. Nutritional properties and ability to grow under limited water supply of ora-pro-nobis are known, but little information is available about the growth behavior and nutritional composition of this plant when cultivated under temperate humid climate. Therefore, we evaluated the phenology of the plant, including observation of new leaves, flowering, fruiting and relating it with the climate changes. Also, we analyzed some physicochemical characteristics (humidity, leaf area, height, protein, color, total phenolic content and antioxidant activity) of ora-pro-nobis cultivated in Pelotas, Rio Grande do Sul, Brazil. We observed that ora-pro-nobis developed normally, but with a quiescent state in the winter, without producing leaves. Flowering of the plant started in March and the fructification started one month later. All physicochemical characteristics varied through the period of cultivation. Our findings support that cultivation of ora-pro-nobis for production of leaves is feasible under temperate and humid climate.
\end{abstract}

Keywords: Ora-pro-nobis, Cactaceae, quiescent state, phenology.

\section{RESUMO}

\section{Pereskia aculeata cultivada no sul do Brasil}

Pereskia aculeata, conhecida popularmente no Brasil como ora-pro-nobis, é nativa de regiões tropicais e de clima seco. Esta cactácea possui folhas suculentas e comestíveis, com altos teores de proteína, minerais, vitaminas e fibras. Propriedades nutricionais e caracterização de crescimento em regiões de clima seco já são conhecidas sobre essa planta, porém muito pouco se sabe sobre a possibilidade do seu cultivo e composição nutricional em áreas de clima temperado e úmido. Por isso, decidiu-se avaliar a fenologia da planta, incluindo a observação da formação de novas folhas, flores e frutos e a relação com as mudanças climáticas. Também analisou-se algumas das propriedades físico-químicas (umidade, área foliar, altura, proteína, cor, fenóis totais e atividade antioxidante) da planta ora-pro-nobis cultivada em Pelotas, Rio Grande do Sul, Brasil. Foi observado que ora-pro-nobis se desenvolveu normalmente, porém durante o inverno a planta permaneceu no estado de quiescência e não produziu folhas. $\mathrm{O}$ início da floração ocorreu no mês de março e a frutificação no mês seguinte. Todas as análises físico-químicas variaram durante os meses de cultivo avaliados. Os resultados sugerem que o cultivo da planta ora-pro-nobis para produção de folhas é possível em regiões de clima temperado e úmido.

Palavras-chave: Ora-pro-nobis, Cactaceae, quiescência, fenologia.

\section{Received on August 28, 2017; accepted on July 5, 2018}

$P_{a}^{2}$ ereskia aculeata (ora-pro-nobis) is a plant member of the Cactaceae family and is found in tropical areas from south United States to south Brazil. It is known, popularly, as ora-pro-nobis and in some Latin American countries is known as Barbados Gooseberry (Takeiti et al., 2009; Sharif et al., 2013).

Ora-pro-nobis is a perennial shrub, very resistant to drought, and has scramble vine characteristics. Flowers are white and small, fruits are small yellow berries, and also, the plant has spines at the stems and large leaves (Brasil, 2010).

Ora-pro-nobis has succulent and edible leaves, which can be used in many preparations, such as salads, stews, flours, breads, pies and pastas (Rocha et al., 2008). Recent studies (Silva et al., 2017) show that ora-pronobis is safe for consumption in terms of acute toxicity and cytotoxicity. Other than food, the plant can be used ornamentally or cultivated for honey production once it is rich in pollen and nectar. Folk medicine practitioners have been known to use ora-pro-nobis as antiinflammatory, emollient, expectorant and antisyphilitic (Sartor et al., 2010).

Ora-pro-nobis leaves are rich in protein (28.4 g $100 \mathrm{~g}^{-1}$ of dry weight) when compared with other vegetables source of protein, like black beans

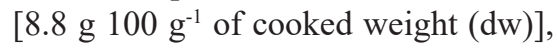

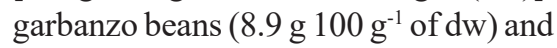
lentils (9.0 g $100 \mathrm{~g}^{-1}$ of dw) (Takeiti et al., 2009; USDA, 2014).

Also, this plant is a remarkable source of nutritionally important minerals (Takeiti et al., 2009; Oliveira et al., 2013). Fresh ora-pro-nobis leaves contains more calcium (20.0 fold), iron ( 5.7 fold) and zinc (3.3 fold) than kale, spinach, and pumpkin seeds, respectively, considered rich vegetable sources for these minerals (Takeiti et al., 2009; USDA, 2014). Ora-pro-nobis 
leaves contain high levels of fiber (39.1 g $100 \mathrm{~g} \mathrm{~g}^{-1}$ of dw), vitamin C (185.8 mg $100 \mathrm{~g}^{-1}$ of dw) and folic acid (19.3 mg $100 \mathrm{~g}^{-1}$ of dw) (Takeiti et al., 2009).

Therefore, ora-pro-nobis could be a good alternative to many common food sources, especially for vegetarians, because it has high levels of minerals and proteins (Takeiti et al., 2009).

Ora-pro-nobis is known to be native from tropical dry forests (Takeiti et al., 2009; Brasil, 2010). To our knowledge, growth behavior and composition of this plant when cultivated under a temperate humid climate is unknown. Therefore, the goal of this study was to evaluate phenological and physicochemical characteristics of ora-pro-nobis cultivated in Pelotas, Rio Grande do Sul, Brazil, under temperate and humid climate.

\section{MATERIAL AND METHODS}

\section{Plant material}

Ora-pro-nobis was cultivated at the Brazilian Agricultural Research Corporation (Embrapa Clima Temperado), located in Pelotas, Brazil. The 21 plants utilized in this experiment were divided into 3 lots. Plants were spaced $100 \mathrm{~cm}$ x $80 \mathrm{~cm}$ without irrigation and pest control. Harvest was done monthly, between December 2012 and June 2013. In the moment of harvest, the 21 plants were measured, to determine height. Also, phenological aspects were determined observing new leaves, flowering and fruiting. These processes were related with climate changes, as precipitation, radiation and temperature (Marques \& Oliveira, 2004).

Harvested leaves were cleaned, milled to a fine powder in a ball mill in liquid nitrogen and stored at $-80^{\circ} \mathrm{C}$ for future analyzes (antioxidant activity, phenol and protein). Fresh leaves were also analyzed for humidity, color and area.

\section{Physicochemical evaluations}

To determine humidity, 10 leaves per lot were weighted and dried during 24 hours in a forced air oven at $105^{\circ} \mathrm{C}$, according AOAC (2012). Leaf area was determined in 10 leaves per lot, based on the use of an automated infrared imaging system, LI-COR-3100C (LI-COR Inc., Lincoln, Nebraska, USA). Plant height was assessed using a tape measure, according to Silva et al. (2012).

Color was determined using a colorimeter (Minolta ${ }^{\circledR}$, Model CR 300). We measured lightness $\left(\mathrm{L}^{*}\right)$, redness $\left(a^{*}\right)$ and yellowness $\left(b^{*}\right)$, in 3 parts of each leaf, and 10 leaves per lot, with a total of 30 leaves per month. The parameters of color were expressed in lightness, where $L^{*}=0$ is completely black, and $\mathrm{L}^{*}=100$ is completely white; and Hue angle $\left(\mathrm{H}^{*}\right)$, calculated from $\mathrm{H}^{*}=[\operatorname{Arctan}(\mathrm{b} / \mathrm{a})]$, where $\mathrm{H}^{*}=0$ is red, $\mathrm{H}^{*}=90$ is yellow, $\mathrm{H}^{*}=180$ is green and $\mathrm{H}^{*}=270$ is blue, as described by Cogo et al. (2011).

Antioxidant activity was estimated using the free radical 2,2-diphenyl1-picrylhydrazyl (DPPH) scavenging assay method, adapted from Kedare \& Singh (2011). Extraction was performed using methanol with 1:4 proportion and stored at $4^{\circ} \mathrm{C}$ for $24 \mathrm{~h}$; after that, the extract was centrifuged (12000 rpm) for 15 minutes. The absorbance of samples was measured at $517 \mathrm{~nm}$ and antioxidant activity was expressed as $\mathrm{g}$ of trolox $/ \mathrm{kg}$ of fresh leaves.

The total phenolic content of orapro-nobis was determined by FolinCiocalteu method, adapted from Medina (2011). Extraction lasted $2 \mathrm{~h}$, using methanol in the proportion 1:10 and stirring every 15 minutes. Results were expressed as $\mathrm{g}$ of galic acid equivalent (GAE) per kg of fresh leaves.

Protein of fresh leaves was estimated using the microkjeldahl method, according to the AOAC (2012). The value 6.25 was used to convert nitrogen into protein.

\section{Statistical analysis}

All analyzes were performed in triplicate. Obtained data of all physicochemical evaluations were analyzed by descriptive statistics for every month and compiled into graphs using SigmaPlot 10.0 software. Person's correlation was used to compare antioxidant activity and total phenolic content, using the Statistical Analysis Software (SAS) for Windows V8, at 5\% significance $(p<0.05)$.

\section{RESULTS AND DISCUSSION}

It is possible to cultivate ora-pronobis in temperate and humid areas. However, it is important to consider that, during winter, when exposed to low temperatures and frost, the plant loses leaves and stays in a quiescent state. Quiescence is a common state in seeds, but it can occur also in the entire or in parts of the plant. Normally, quiescence is a preparation for winter and is a strategy to conserve energy and carbohydrate by restraining growth (Luo et al., 2011). We started to analyze the plants in June 2012, but because of the quiescent state, we only had enough leaves to analyze between December 2012 and June 2013.

Phenology is the sequential developmental stages of the annual growth cycle and their timing. In our study we analyzed the occurrence of new leaves, flowering and fructification (Table 1).

Observations were made at the end of spring, in December, when temperature was higher, frost subsided, and new leaves started to grow back. After three months, in March, we noticed that flowering had started in the first plants, and one month later, in April, the fruiting started. Again, when temperature decreased, in June, leaves started to fall, ending the cycle of orapro-nobis in south Brazil. Temperature was found to be an essential factor for growth and development of this species. It is known that temperature affects photosynthesis and development of shoots (Ushio et al., 2008).

In temperate climates, warm temperatures often act as flowering triggers. Also, rain is an important timer for flowering in shrubs. There is a difference between fruiting in temperate and tropical areas. In temperate regions fruiting normally starts late in the summer or in the autumn, lasting for one and a half month in average. The fruit production is largely controlled by the accumulation of enough photosynthesis, which can only occur towards the end of the growing season (Fenner, 
Table 1. Temperature, radiation, precipitation and phenological aspects during Pereskia aculeata cultivation from June 2012 to June 2013. Pelotas, UFPel, 2013.

\begin{tabular}{lcccccc}
\hline \multirow{2}{*}{ Month } & \multicolumn{3}{c}{ Temperature $\left({ }^{\circ} \mathbf{C}\right)$} & Radiation (cal/ & $\begin{array}{c}\text { Precipitation } \\
(\mathbf{m m})\end{array}$ & Phenological aspect \\
\cline { 2 - 4 } $\left.\mathbf{c m}^{2} / \mathbf{d}\right)$ & Min & Max & Average & & Quiescence \\
July/2012 & 5.6 & 16.8 & 10.4 & 221.7 & 138.5 & Quiescence \\
August/2012 & 12.6 & 22.9 & 16.7 & 263.3 & 103.1 & Quiescence \\
September/2012 & 12.3 & 21.3 & 16.2 & 309.9 & 115.3 & Quiescence \\
October/2012 & 15.9 & 23.6 & 19.2 & 338.5 & 106.5 & - \\
November/2012 & 11.6 & 27.0 & 21.2 & 504.8 & 52.1 & New leaves \\
December/2012 & 18.7 & 29.3 & 23.6 & 502.0 & 175.1 & New leaves \\
January/2013 & 17.5 & 27.5 & 22.3 & 548.5 & 69.2 & - \\
February/2013 & 19.1 & 28.0 & 22.8 & 454.9 & 177.3 & Flowering \\
March/2013 & 15.2 & 25.8 & 19.8 & 390.4 & 27.6 & Flowering \& Fruiting \\
April/2013 & 13.8 & 24.5 & 18.3 & 306.7 & 147.4 & Flowering \& Fruiting \\
May/2013 & 10.5 & 20.6 & 14.6 & 211.8 & 84.1 & Quiescence Started \\
June/2013 & 8.0 & 18.4 & 12.5 & 202.9 & 75.8 & \\
\hline
\end{tabular}

Source: Estação Agrometeorológica de Pelotas, RS (UFPEL/EMBRAPA/INMET: http://www.cpact.embrapa.br/agromet). The minimum (Min) and maximum (Max) temperatures correspond to the mean of minimum and maximum temperatures in each month, respectively.

1998). In our study we observed that temperature was the most important factor for flowering. Also, fruiting started in autumn, lasting two months in average. A single-year study was sufficient to demonstrate the ability of ora-pro-nobis to grow under temperate and humid climate, but cannot provide complete information on phenological changes among the years. According to Fenner (1998), long-term (3-5 year) investigation is required to determine phenological modifications accurately.

Color, expressed as lightness and Hue angle, is shown in Figure 1. Lightness presented the higher level in March $(\mathrm{L}=51.32)$, meaning that this was the month when leaves had the lightest colors, coinciding with flowering start. The values of Hue angle showed that leaves presented colors between yellow and green during all months. In December and March, leaves were more yellowish and in January more greenish. These color changes of leaves are probably due to local climate conditions. In January, when leaves were more greenish, the solar radiation reached its maximum $\left(548.5 \mathrm{cal} / \mathrm{cm}^{2} / \mathrm{d}\right)$ (Table 1). Therefore, it could be argued that solar radiation was a limiting factor for the plant development under temperate climate. Pereskia species have typically been described as drought deciduous, suggesting that Pereskia water relations are different from those of specialized core cacti and that Pereskia regulates water loss in the same way as a typical
C3 woody plant (Edwards \& Diaz, 2006). Therefore, in comparison to the stem color of specialized core cacti, the color of leaves from Pereskia species is expected to respond faster to changes in climate conditions (rain, temperature and solar radiation). Chlorophyll is the most common pigment found in plants and is responsible for their characteristic green color. The bright green color of vegetables is often associated to their freshness (Calvano et al., 2015).

Average height of plants increased almost 4 folds during the seven months period of analyzes. The least average leaf area $\left(14.82 \mathrm{~cm}^{2}\right)$ was observed in December, due to the quiescence state period months before. After that, leaves started to grow, reaching the largest
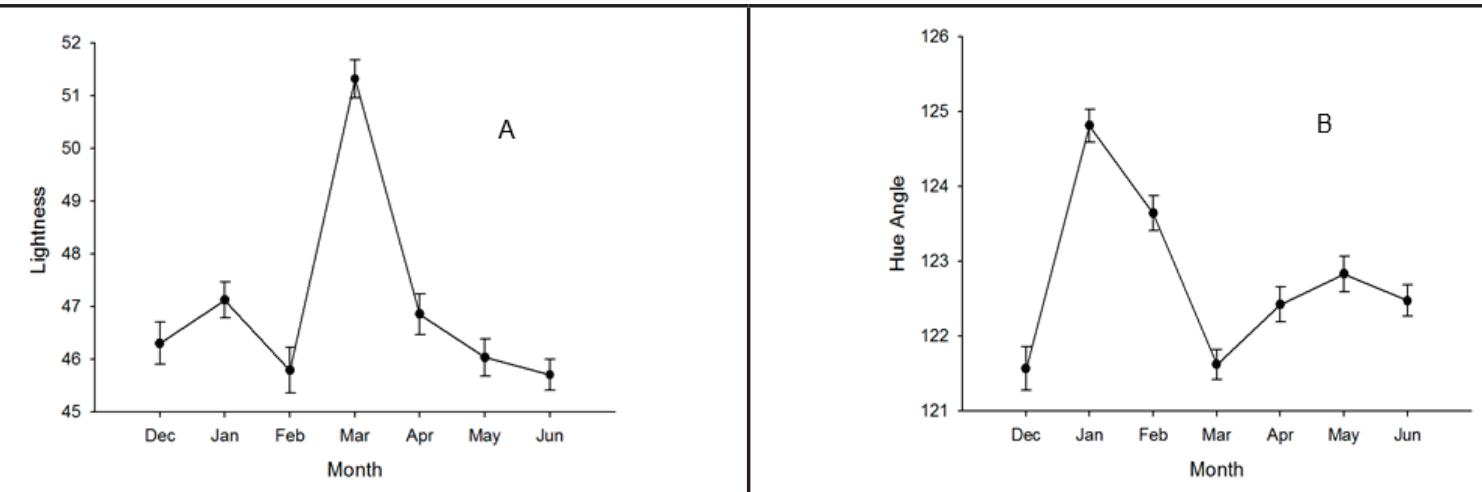

Figure 1. Color, expressed in lightness and Hue angle, of Pereskia aculeata leaves from December 2012 to June 2013. Pelotas, UFPel, 2013. 
average size $\left(33.11 \mathrm{~cm}^{2}\right)$ in February (Figure 2). Monitoring changes of leaf area is important for assessing growth and vigor of plants. Frost, storm, defoliation, drought, and management practice commonly cause reduction of leaf area, therefore decreasing the productivity of the plant (Breâda, 2003).

Humidity of ora-pro-nobis leaves remained around $880 \mathrm{~g} \mathrm{~kg}^{-1}$ for 7 months, reaching the lowest average value (861.11 $\mathrm{g} \mathrm{kg}^{-1}$ ) in February. Protein content was higher in December 2012 (27.23 $\left.\mathrm{g} \mathrm{kg}^{-1}\right)$ and June 2013 (27.22 $\left.\mathrm{g} \mathrm{kg}^{-1}\right)$ and lower in February $(21.35 \mathrm{~g}$ $\mathrm{kg}^{-1}$ ) (Figure 2). Maintenance respiration is known to be increased by higher temperatures (Modi, 2007). In this study, higher leaf protein turnover under higher temperature conditions may have been responsible for tendency of lower protein contents under higher temperature growth conditions. Antioxidant activity, measured with the DPPH scavenging assay, as well as total phenolic content, reached the highest level, $44.99 \mathrm{~g}$ of Trolox/kg of fresh plant and $2.66 \mathrm{~g}$ of $\mathrm{GAE} / \mathrm{kg}$ of fresh plant, respectively, on April (Figures 2E and F). Antioxidant activity and total phenolic content had some correlation $(\mathrm{r}=0.71 ; \mathrm{p}<0.0001)$.

Pinto et al. (2012), researching ora-pro-nobis leaves, found by thin layer chromatography, that phenol was the main antioxidant compound. There are many studies showing that total phenol compound has stronger positive correlation with antioxidant activity in vegetables (Aires et al., 2011; Bhandari \& Kwak, 2015). Phenolic compounds are among the most important components on the quality of vegetables and fruits. They contribute to organoleptic characteristics like color and taste and promote beneficial effect to human health (Sancho et al., 2011; Zielinski et al., 2014).

Ora-pro-nobis developed adequately, but with a quiescent state in the winter (without producing leaves). Flowering of the plant started in March and

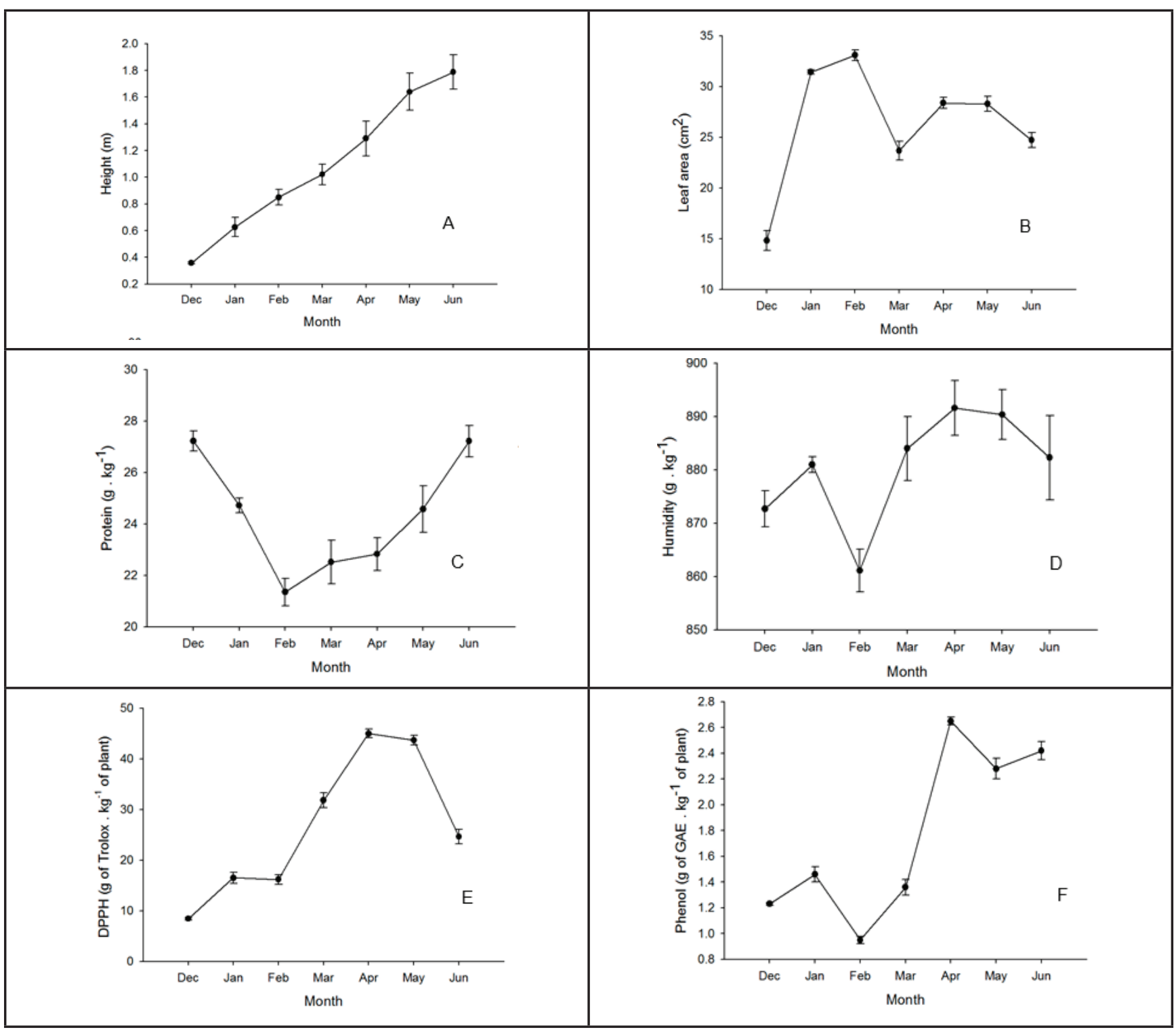

Figure 2. Pereskia aculeata during cultivation in southern Brazil (December 2012 to June 2013). A= height; $B=$ leaf area; $C=$ protein; $D=$ humidity; $\mathrm{E}=$ antioxidant activity (DPPH); $\mathrm{F}=$ total phenolic content (phenol). Pelotas, UFPel, 2013. 
fructification one month later. The physicochemical characteristics (humidity, leaf area, protein, color, total phenolic content and antioxidant activity) varied throughout cultivation period. All our findings support that cultivation of ora-pro-nobis for production of leaves is feasible under temperate and humid climate in south Brazil.

\section{ACKNOWLEDGEMENTS}

The authors acknowledge FAPERGS and CAPES, for funding this work, and Embrapa for supplying the plants, all from Brazilian Government.

\section{REFERENCES}

AIRES, A; FERNANDES, C; CARVALHO, R; BENNET, RN; SAAVEDRA, MJ; ROSA, EA. 2011. Seasonal effects on bioactive compounds and antioxidant capacity of six economically important Brassica vegetables. Molecules 16: 6816-6832.

AOAC - Association of Official Analytical Chemists. 2012. Official Methods of Analysis. Washington: AOAC.

BHANDARI, SR; KWAK, JH. 2015. Chemical composition and antioxidant activity in different tissues of Brassica vegetables. Molecules 20: 1228-1243.

BRASIL. Ministério da Agricultura, Pecuária e Abastecimento. 2010. Manual de Hortaliças não-convencionais. Available at $<$ http://www. abcsem.com.br/docs/manual_hortalicas_web. pdf $>$. Accessed March 5, 2013.

BREÂDA, NJJ. 2003. Ground-based measurements of leaf area index: a review of methods, instruments and current controversies. Journal of Experimental Botany 54: 2403-2417.

CALVANO, CD; VENTURA, G; CATALDI, TR; PALMISANO, F. 2015. Improvement of chlorophyll identification in foodstuffs by MALDI ToF/ToF mass spectrometry using 1,5-diaminonaphthalene electron transfer secondary reaction matrix. Analytical and
Bioanalytical Chemistry 407: 6369-6379.

COGO, SLP; CHAVES, FC; SCHIRMER, MA; ZAMBIAZI, RC; NORA, L; SILVA, JA; ROMBALDI, CV. 2011. Low soil water content during growth contributes to preservation of green colour and bioactive compounds of cold-stored broccoli (Brassica oleraceae L.) florets. Postharvest Biology and Technology 60: 158-163.

EDWARDS, EJ; DIAZ, M. 2006. Ecological physiology of Pereskia guamacho, a cactus with leaves. Plant Cell and Environment 29: 247-256.

FENNER, M. 1998. The phenology of growth and reproduction in plants. Perspectives in Plant Ecology, Evolution and Systematics 1: 78-91.

KEDARE, SB, SINGH, RP. 2011. Genesis and development of DPPH method of antioxidant assay. Journal of Food Science and Technology 48: 412-422.

LUO, FL; NAGEL, KA; SCHARR, H; ZENG, B; SCHURR, U; MATSUBARA, S. 2011. Recovery dynamics of growth, photosynthesis and carbohydrate accumulation after desubmergence: a comparison between two wetland plants showing escape and quiescence strategies. Annals of Botany 107: 49-63.

MARQUES, MCM; OLIVEIRA, PEAM. 2004. Fenologia de espécies do dossel e do subbosque de duas Florestas de Restinga na Ilha do Mel, sul do Brasil. Revista Brasileira de Botânica 27: 713-723.

MEDINA, MB. 2011. Simple and rapid method for the analysis of phenolic compounds in beverages and grains. Journal of Agricultural and Food Chemistry 59: 1565-1571.

MODI, AT. 2007. Growth temperature and plant age influence on nutritional quality of Amaranthus leaves and seed germination capacity. Water AS 33: 369-375.

OLIVEIRA, DCS; WOBETO, C; ZANUZO, MR; SEVERGNINI, C. 2013. Composição mineral e teor de ácido ascórbico nas folhas de quatro espécies olerícolas não-convencionais. Horticultura Brasileira 31: 472-475.

PINTO, CCP; SANTOS, RC; MACHADO, DC; FLORÊNCIO, JR; FAGUNDES, EMS; ANTINARELLI, LMR; COIMBRA, ES; RIBEIRO, A; SCIO, E. 2012. Cytotoxic and antioxidant activity of Pereskia aculeata Miller. Pharmacology Online 3: 63-69.

ROCHA, DRC; PEREIRA JÚNIOR, GA; VIEIRA, G; PANTOJA, L; SANTOS, AS; PINTO, NAVD. 2008. Macarrão adicionado de ora-pro-nobis (Pereskia aculeata Miller) desidratado. Alimentos e Nutrição 19: 459465.

SANCHO, LEGG; YAHIA, EM; GONZÁLEZAGUILAR, GA. 2011. Identification and quantification of phenols, carotenoids, and vitamin $\mathrm{C}$ from papaya (Carica papaya L., cv. Maradol) fruit determined by HPLC-DADMS/MS- ESI. Food Research International 44: 1284-1291.

SARTOR, CFP; AMARAL, V; GUIMARÃES, HET; BARROS, KN; FELIPE, DF; CORTEZ, LER; VELTRINI, VC. 2010. Estudo da ação cicatrizante das folhas de Pereskia Aculeata. Saúde e Pesquisa 3: 149-154.

SHARIF, KM; RAHMAN, MM; ZAIDUL, ISM; JANNATUL, A; AKANDA, MJH; MOHAMED, A; SHAMSUDIN, SH. 2013. Pharmacological relevance of primitive leafy cactuses Pereskia. Research Journal of Biotechnology 8: 134-142.

SILVA, GF; CURTO, RA; SOARES, CPB; PIASSI, LC. 2012 Avaliação de métodos de medição de altura em florestas naturais. Revista Árvore 36: 341-348.

SILVA, DO; SEIFERT, M; NORA, FR; BOBROWSKI, VL; FREITAG, RA; KUCERA, HR; NORA, L; GAIKWAD, NW. 2017. Acute toxicity and cytotoxicity of Pereskia aculeata, a highly nutritious cactaceae plant. Journal of Medicinal Food 20: 403-409.

TAKEITI, CY; ANTONIO, GC; MOTTA, EMP; COLLARES-QUEIROZ, FP; PARK, KJ. 2009. Nutritive evaluation of a nonconventional leafy vegetable (Pereskia aculeata Miller). International Journal of Food Sciences and Nutrition 60: 148-160.

USDA - United States Department of Agriculture. National nutrient database for standard reference release 27. Available at $<\mathrm{http}$ :/ ndb.nal.usda.gov/ndb/foods $>$ accessed April 26, 2014 .

USHIO, A; MAE, T; MAKINO A. 2008. Effects of temperature on photosynthesis and plant growth in the assimilation shoots of a rose. Soil Science and Plant Nutrition 54: 253-258.

ZIELINSKI, AA; ÁVILA, S; ITO, V; NOGUEIRA, A; WOSIACKI, G; HAMINIUK, CW. 2014. The association between chromaticity, phenolics, carotenoids, and in vitro antioxidant activity of frozen fruit pulp in Brazil: An application of chemometrics. Journal of Food Science 79: 510-516 